\title{
PEMODELAN DAN SIMULASI BEBAN NON-LINIER 3-FASA DENGAN METODA SUMBER ARUS HARMONIK
}

\author{
Rizka Amalia ${ }^{1}$ dan Refdinal Nazir ${ }^{2}$ \\ Teknik Elektro Universitas Andalas, \\ 1Email: r3zkamlia@gmail.com, ${ }^{2}$ Email: refdinalnazir@yahoo.co.id
}

\begin{abstract}
Abstrak-Perkembangan teknologi dibidang elektronika yang sangat pesat menyebabkan meningkatnya penggunaan beban non-linier, baik di rumah tangga, perkantoran, industi atau bidang lainnya. Harmonisa yang ditimbulkan beban non-linier sangat unik, artinya setiap beban non-linier berbeda sifat dan karakteristik harmonisa yang dihasilkannya. Biasanya beban non-linier memiliki rangkaian ekivalen yang lebih rumit, sehingga lebih sulit di jabarkan untuk tujuan melihat sifat dan karakteristik masing-masing beban non-linier. Oleh Karena itu dibutuhkan kajian pemodelan beban non-linier untuk mempermudah melihat sifat dan karakteristiknya. Pada kajian ini data arus harmonisa menjadi dasar pembuatan model simulasi beban non-linier menggunakan sumber arus pada simulink MATLAB. Dengan menggunakan aturan beda fasa dan urutan fasa sumber arus dirangkai secara paralel, dimana setiap sumber arus mewakili satu orde harmonisa. Dari simulasi yang dilakukan didapatkan hasil yang mendekati hasil pengujian di laboratorium. Gelombang arus harmonisa sama pada fasa a, fasa b dan fasa c hanya saja bergeser $120^{\circ}$.
\end{abstract}

\section{Kata Kunci : Generator Induksi Penguatan Sendiri (GIPS), Beban Nonlinier, Harmonisa, Total Harmonic Distortion (THD).}

\begin{abstract}
The fast technological development in electronics fields leads to the increasing use of nonlinear loads in households, offices, industry, or other fields. Harmonic caused by non-linear loads are very unique, which means that each non-linear load produces different nature a characteristcs of the resulting harmonic. Usually, non-linier loads have so complicated equivalent circuit that it is more difficult to describe the nature and characteristic of each non-linier load. Therefore, in order to make the study easier, modeling approach of non-linier loads is needed so that it makes it easier to see the nature and characteristics of them. In this approach, harmonic current wave is used as the base to make simulation model of nonlinear load using current source in SIMULINK MATLAB. By using the concept of phase shifted and phase sequences current source are connected in parallel in which each current source represent one harmonic order. From simulation, it is found out that the result is approximately the same as that of laboratory test. The harmonic current wave is the same at phase a, phase b, and phase c, with $120^{\circ}$ shift.
\end{abstract}

\section{Keywords : Self Excited Induction Generator (SEIG), Non-linear load, Harmonic, Total Harmonic Distortion (THD).}

\section{PENDAhuluan}

Perkembangan teknologi dibidang elektronika yang sangat pesat menyebabkan meningkatnya penggunaan beban non-linier, baik di rumah tangga, perkantoran, industi atau bidang lain. Beberapa contoh beban non-linier yang sering digunakan diantaranya adalah: penyearah (rectifier), lampu hemat energi dan Variable Frequency Drive (VFD). Dari hasil survei CBEMA (Computer and Business Equipment Manufacturing Association) dan LCSE (Liebert Customer Service Engineering) dinyatakan bahwa lebih dari $40 \%$ total beban yang terdapat pada sistem distribusi tenaga listrik moderen adalah berupa beban non-linier, yang didominasi oleh peralatan elektronik [1]. Umumnya, penggunaan beban non-linier bertujuan untuk menghemat energi dan sebagai peralatan kontrol elektronik (ELC). Namun, keuntungan yang dirasakan dalam penggunaan beban non-linier juga di ikuti oleh dampak negatif. Dampak negatif yang ditimbulkan dapat berupa gangguan pada sumber maupun gangguan ke peralatan lain yang tersambung pada sistem kelistrikan yang sama. Gangguangangguan ini biasanya diakibatkan oleh harmonisa yang dihasilkan beban non-linier. Harmonisa yang ditimbulkan beban non-linier sangat unik, artinya setiap beban non-linier berbeda sifat dan karakteristik harmonisa yang dihasilkannya. Biasanya Beban non-linier 
memiliki rangkaian ekivalen yang lebih rumit, sehingga lebih sulit di jabarkan untuk tujuan melihat sifat dan karakteristik masing-masing beban non-linier. Oleh karena itu, untuk mempermudah melihat sifat dan karakteristik beban non-linier dibutuhkan kajian pemodelannya.

Beberapa penelitian yang telah ada tentang pemodelan beban non-linier menggunakan pendekatan matematis dalam penyelesaiannya. Seperti pengaplikasian "discrete time-dynamic filter based on stochastic estimation theory" dalam menentukan dan menghitung besar impedansi atau admitansi suatu harmonisa dengan tepat dan menggunakannya melalui program simulasi [2]. Penelitian lainnya menggunakan pendekatan algoritma rekrusiv untuk mengidentifikasi admitansi beban nonlinier walaupun komponennya berubah terhadap waktu [3]. Kedua penelitian ini menggunakan pendekatan matematis dalam memodelkan beban non-linier, namun belum ditemukan pemodelan beban non-linier yang menggunakan pendekatan data lapangan yang memodelkan serta menganalisisnya menggunakan program simulink.

Berlatar belakang hal diatas, diperlukan kajian dalam membuat model beban non-linier 3-fasa dalam simulasi menggunakan simulink MATLAB. Dalam penelitian ini diajukan satu metode pemodelan beban non-linier pada simulasi dengan meggunakan komponen sumber arus yang dirangkai dan di susun sesuai dengan fasa dan aturan urutan fasanya. Setiap komponen sumber arus merupakan perwakilan setiap orde arus harmonisa beban yang akan dimodelkan. Data setiap hasil komponen harmonisa didapatkan dari data spektrum pengukuran laboratorium.

\section{PENGERTIAN BEBAN LINIER DAN BEBAN NON-LINIER}

Beban linier merupakan beban yang impedansinya selalu konstan sehingga arus selalu sebanding dengan tegangan setiap waktunya. Beban linier mengikuti hukum Ohm yang menyatakan bahwa arus sebanding dengan tegangan. Gelombang arus beban linier akan sama dengan bentuk gelombang tegangan. Apabila diberi tegangan sinusoidal, maka arus yang mengalir ke beban linier juga berbentuk gelombang sinusoidal sehingga tidak terjadi distorsi. Gambar 1 berikut adalah contoh bentuk gelombang arus dan tegangan beban linier [4].

Pada umumnya beban linier dimodelkan dengan kombinasi antara resistansi dan induktansi, seperti yang diperlihatkan pada gambar 2. Pada beban non linier arus dari sumber masuk ke arah beban.

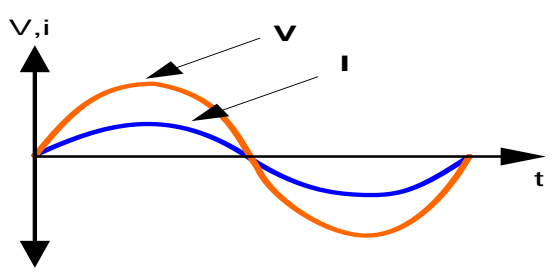

Gambar 1. Bentuk gelombang arus dan tegangan dengan beban linier

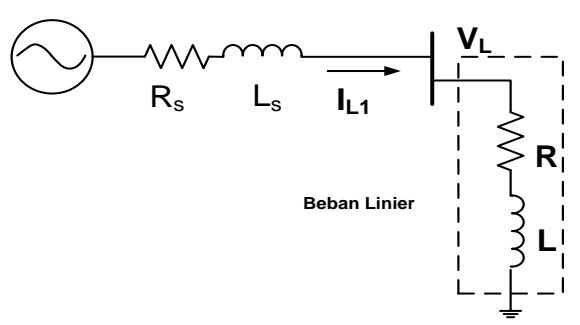

Gambar 2. Pemodelan Beban Linier

Beban non-linier merupakan beban yang menghasilkan gelombang arus tidak sama dengan bentuk gelombang tegangan sehingga terjadi cacat (distorsi) seperti terlihat pada gambar 3.

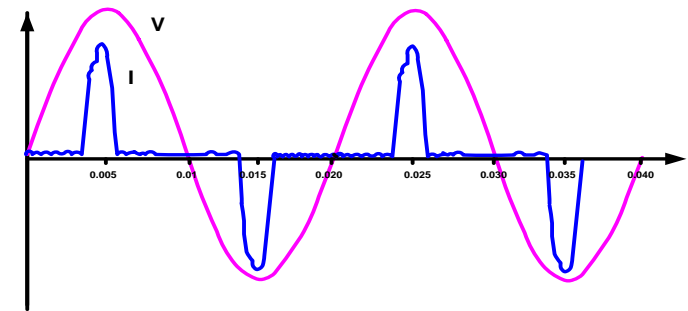

Gambar 3. Bentuk gelombang arus dan tegangan dengan beban linier

Sinyal tegangan dan arus beban non-linier dapat dinyatakan dengan deret fourier seperti pada persamaan 1 . 


$$
v_{t}=V_{0}+\sum_{n=1}^{\infty} \sqrt{2} V_{n} \sin \left(n \omega_{1} t+\theta_{n}\right)
$$

dimana :

$$
\begin{aligned}
& \begin{array}{l}
\omega_{1}=2 \pi f_{1}, \text { untuk } \mathrm{n}=1 \text { sampai } \sim \\
V_{0}=\text { komponen } D C \\
V_{1}, V_{2}, V_{3}, \ldots, V_{n}=\text { nilai puncak gelombang } \\
\quad \text { harmonisa secara berurutan } \\
f_{1} \quad \text { frekuensi fundamental (harmonik } \\
\quad \text { pertama) } \\
n x f_{1}=\text { frekuensi harmonik ke } \mathrm{n} . \\
\theta_{n} \cdot=\text { pergeseran fasa }
\end{array}
\end{aligned}
$$

Beban non-linier seperti peralatan elektronik dapat dimodelkan sebagai beban linier $R$ dan $L$ serta sumber arus harmonisa seperti pada gambar 3(a). Bila model pada gambar 3(a) di gunakan dalam perhitungan, maka tidak sesuai dengan aturan deret fourier pada persamaan 1 dimana nilai harmonisa merupakan penjumlahan orde pertama dan orde-orde berikutnya. Selain itu, jika komponen fundamental (orde 1) tetap digambarkan sebagai $R$ dan $L$, maka arah arus menuju $R$ dan $L$ sedangkan orde lain yang di modelkan dengan komponen sumber arus yang arah arusnya berkebalikan (keluar dari sumber arus) sehingga arah arus saling bertentangan antara orde satu dengan orde-orde lainnya. Model pada gambar 3 (a) secara ril mudah dipahami namun tidak sesuai dengan teori deret fourier yang menyatakan penjumlahan fundamental dan komponen harmonisanya. Dalam hal pengukuran kita tidak bisa memisahkan antara fundamental dengan harmonisanya yang artinya semua komponen fundamental dan orde lain memiliki arah arus yang sama [5].

Guna pendekatan dalam simulasi dan perhitungannya, munculah pemodelan seperti pada gambar 3 (b). Komponen fundamental beban non-linier atau yang disebut juga harmonisa orde pertama tidak lagi dimodelkan sebagai resistansi dan induktansi seperti pada gambar 3(a), akan tetapi di modelkan sebagai sumber arus sama halnya dengan komponen harmonisa orde lainnya. Komponen arus fundamentalnya di beri nama $I_{L}$, komponen harmonisa orde ke-5 diberi nama $I_{5}$ dan komponen harmonisa orde ke-7 diberi nama $I_{7}$ [5].

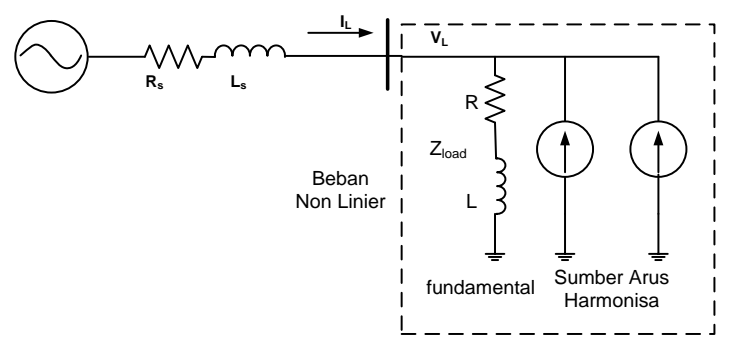

(a) Pemodelan beban nonlinier [4][6]

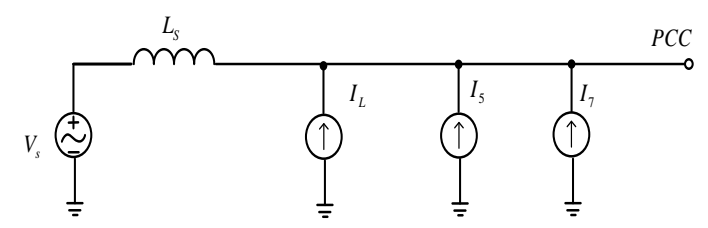

(b) Pemodelan beban nonlinier dalam simulasi dan perhitungan [5]

Gambar 4. Pemodelan beban nonlinier

\section{PEMODELAN BEBAN NONLINIER 3- FASA}

Pada kajian ini beban non-linier diwakili oleh lampu hemat energi (LHE) yang di pasang seri beberapa buah di setiap fasanya seperti terlihat pada gambar 5 .

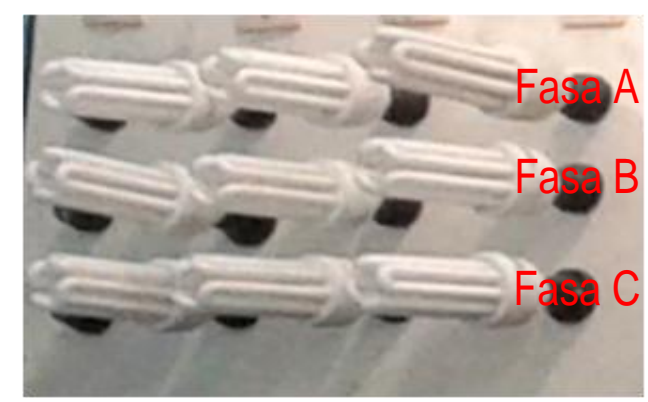

Gambar 5. LHE sebagai perwakilan beban nonlinier

Untuk mendapatkan model simulasi beban non-linier, data harmonisa diambil di laboratorium pada tingkat beban yang bervariasi. Dengan menganggap sumber harmonisa sebagai sumber arus, kemudian urutan orde harmonisa setiap beban yang diukur menggunakan Power Analyzer seperti pada tabel 5 di inputkan ke parameter sumber arus dengan memperhatikan urutan fasanya seperti pada gambar 5 . 


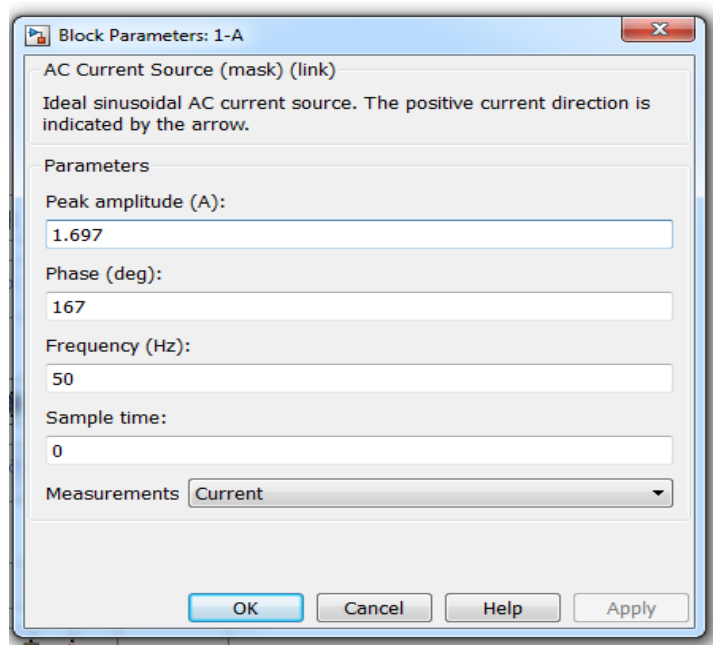

Gambar 6. Parameter sumber arus sebagai sumber harmonisa

Tabel 1. Contoh urutan orde harmonisa lampu hemat energi beban 810 Watt

\begin{tabular}{|c|c|c|c|c|c|c|c|c|c|}
\hline \multicolumn{4}{|c|}{$\mathrm{V}=221.8 \mathrm{~V}$} & \multicolumn{2}{|c|}{$\mathrm{V}==7906$} & \multicolumn{4}{|c|}{$\mathrm{V} C F=1.44$} \\
\hline \multicolumn{4}{|c|}{$I_{\text {man }}=1.2 \mathrm{~A}$} & \multicolumn{2}{|c|}{$I==44.6 \%$} & \multicolumn{4}{|c|}{ I CF $=1.90$} \\
\hline orde & $\mathbf{V h}$ & $\mathbf{V h}{ }^{\mathbf{O}}$ & ${ }_{\%}$ Th & $\mathrm{Ih}^{\circ}$ & orde & $\begin{array}{l}\mathbf{Y h} \\
\%_{0}\end{array}$ & vito & $\underset{\%}{\text { Ih }}$ & $\mathrm{Ih}^{\circ}$ \\
\hline 0 & 0.0 & $0^{\circ}$ & 0.0 & $0^{2}$ & 26 & 0.0 & 0 & 0.1 & -95 \\
\hline 1 & 100 & $0^{\circ}$ & 100 & $0^{\circ}$ & 27 & 0.0 & 0 & 1.6 & 158 \\
\hline 2 & 0.0 & $0^{\circ}$ & 0.2 & $-10^{2}$ & 28 & 0,0 & 0 & 0.1 & -165 \\
\hline 3 & 45 & $17^{\circ}$ & 19 & $43^{\circ}$ & 29 & 0.1 & 165 & 5.7 & 18 \\
\hline 4 & 0.0 & $0^{2}$ & 0.2 & $60^{\circ}$ & 30 & 0,0 & 0 & 0.1 & 140 \\
\hline 5 & 63 & $0^{\circ}$ & 327 & $-163^{\circ}$ & 31 & 0.0 & 0 & 3.6 & -94 \\
\hline 6 & 0.0 & $0^{\circ}$ & 0.1 & $52^{\circ}$ & 32 & 0,0 & 0 & 0.1 & 25 \\
\hline 7 & 1.3 & -56 & 173 & 93 & 0 & 0.0 & 0 & 1.6 & -67 \\
\hline 8 & 0.0 & 0 & 0.3 & -174 & 34 & 0.0 & 0 & 0.2 & -86 \\
\hline 9 & 0.2 & -49 & 1.9 & 93 & 35 & 0.0 & 0 & 4.5 & 154 \\
\hline 10 & 0.0 & 0 & 0.0 & 0 & 36 & 0.0 & 0 & 0,1 & -54 \\
\hline 11 & 0.7 & -137 & 155 & -30 & 37 & 0.0 & 0 & 2,7 & 46 \\
\hline 12 & 0.0 & 0 & 0.1 & 26 & 38 & 0.0 & 0 & 0.2 & 56 \\
\hline 13 & 0.4 & 152 & 9.8 & -142 & 39 & 0.0 & 0 & 1.5 & 66 \\
\hline 14 & 0.0 & 0 & 0.1 & -64 & 40 & 0.0 & 0 & 0.3 & 180 \\
\hline 15 & 0,1 & 174 & 1.6 & -104 & 41 & 0,0 & 0 & 3.6 & -69 \\
\hline 16 & 0.0 & 0 & 0.1 & 122 & 42 & 0.0 & 0 & 0.1 & 72 \\
\hline 17 & 0.3 & 86 & 100 & 108 & 43 & 0,0 & 0 & 2,1 & -174 \\
\hline 18 & 0.0 & 0 & 0.1 & -86 & 44 & 0.0 & 0 & 0.2 & -62 \\
\hline 19 & 0.1 & 0 & 6.5 & -5 & 45 & 0.0 & 0 & 1,4 & -156 \\
\hline 20 & 0.0 & 0 & 0.1 & 106 & 46 & 0.0 & 0 & 0.0 & 0 \\
\hline 21 & 0.0 & 0 & 1.8 & 21 & 47 & 0.0 & 0 & 3.0 & 68 \\
\hline 22 & 0.0 & 0 & 0.0 & 0 & 48 & 0.0 & 0 & 0.1 & -154 \\
\hline 23 & 0.2 & -48 & 7.3 & -117 & 49 & 0.0 & 0 & 1.7 & -33 \\
\hline 24 & 0,0 & 0 & 0.1 & 40 & 50 & 0,0 & 0 & 0,1 & 63 \\
\hline 25 & 0.1 & -126 & 4.8 & 131 & & & & & \\
\hline
\end{tabular}

Fasa dan urutan fasa ditentukan dengan menjadikan fasa a sebagai fasa referensi dengan beda dua fasa lainnya yaitu fasa b dan fasa $c$ sebesar $-120^{\circ}$ atau $+120^{\circ}$ dari fasa a. Sebagai contoh dari pengukuran harmonisa beban 810 Watt didapatkan urutan orde harmonisa seperti pada tabel 2.

Komponen yang diambil adalah komponen orde harmonisa arus $\left(I_{h}\right)$ untuk persentase besaran amplitudo dan komponen $I_{h}{ }^{\mathrm{O}}$ untuk besaran fasanya. Komponen fundamental (orde 1) sudut antara arus dan tegangan yang terukur untuk beban 810 Watt sebesar $167^{\circ}$ dijadikan sebagai patokan referensi sudut untuk fasa berikutnya. Untuk komponen orde 1 fasa a yang merupakan urutan positif (lihat tabel 1), maka sudut fasa a menjadi : $167^{\circ}+0=167^{\circ}$. Untuk orde 1 fasa $b$, sudut fasa menjadi : $167^{\circ}+\left(-120^{\circ}\right)$ $=47^{\circ}$. Untuk orde 1 fasa $\mathrm{c}$, sudut fasa menjadi $167^{\circ}+\left(+120^{\circ}\right)=287^{\circ}$. Untuk komponen harmonisa orde ke 2 yang merupakan urutan negatif (lihat tabel 3), maka sudut fasa a menjadi : $167^{\circ}+\left(-10^{\circ}\right)=157^{\circ}$. Untuk fasa $b$, sudut fasanya menjadi : $157^{\circ}+\left(+120^{\circ}\right)=277^{\circ}$. Dan untuk fasa c menjadi : $157^{\circ}+\left(-120^{\circ}\right)=37^{\circ}$.

Untuk komponen harmonisa orde ke 3 yang merupakan urutan nol (lihat tabel 1), maka sudut fasa a menjadi $167^{\circ}+\left({ }_{+} 43^{\circ}\right)=210^{\circ}$, artinya sudut fasa a, b, c berhimpit pada sudut $210^{\circ}$. Begitu seterusnya untuk setiap orde harmonisa. Dengan demikian akan didapatkan urutan orde harmonisa dengan urutan fasa yang sesuai dengan tabel 2 [7].

Tabel 2. Orde Harmonisa dan Urutan Fasa [7]

\begin{tabular}{|c|c|c|}
\hline $\begin{array}{c}\text { Orde } \\
\text { Harmonisa }\end{array}$ & $\begin{array}{c}\text { Urutan } \\
\text { Fasa }\end{array}$ & Contoh \\
\hline $\begin{array}{c}1,4,7,10, \\
13,16,19, \ldots\end{array}$ & Positif & $\stackrel{\left.\mathrm{P}^{2}\right)}{\stackrel{\mathrm{I}_{\mathrm{a}}}{\longrightarrow}}$ \\
\hline $\begin{array}{c}2,5,8,11 \\
14,17,20, \ldots\end{array}$ & Negatif & $\mathrm{I}_{\mathrm{a} 2}$ \\
\hline $\begin{array}{r}3,5,9,12 \\
15,18,21, \ldots\end{array}$ & Nol & $-\frac{1}{\left.\left.\left.\left.\right|_{1}\right|_{a 3}\right|_{b 3}\right|_{c 3}}$ \\
\hline
\end{tabular}

Setelah semua nilai parameter didapatkan sesuai dengan urutan fasanya, kemudian di diinputkan ke dalam komponen simulink sumber arus sehingga seperti terlihat pada gambar 7. Begitu juga untuk fasa $b$ dan fasa $c$ untuk beban 675 Watt, 540 Watt dan 405 Watt. 


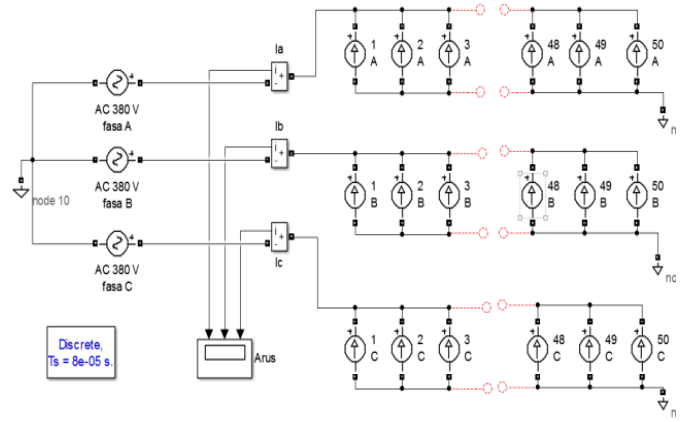

Gambar 7. Model simulasi beban nonlinier menggunakan sumber arus sebagai sumber

\section{HASIL DAN PEMBAHASAN}

Hasil simulasi pemodelan arus harmonisa LHE menggunakan metode pergeseran fsa dan urutan fasa untuk beban 945Watt, 810 Watt, 675 Watt, 540 Watt dan 405 Watt dapat dilihat pada gambar 8 sampai gambar 12 .

Gambar 8 memperlihatkan bentuk gelombang arus LHE 945 Watt yang terlihat sama namun bergeser $120^{\circ}$ antara fasa $a$, fasa $b$ dan fasa c.

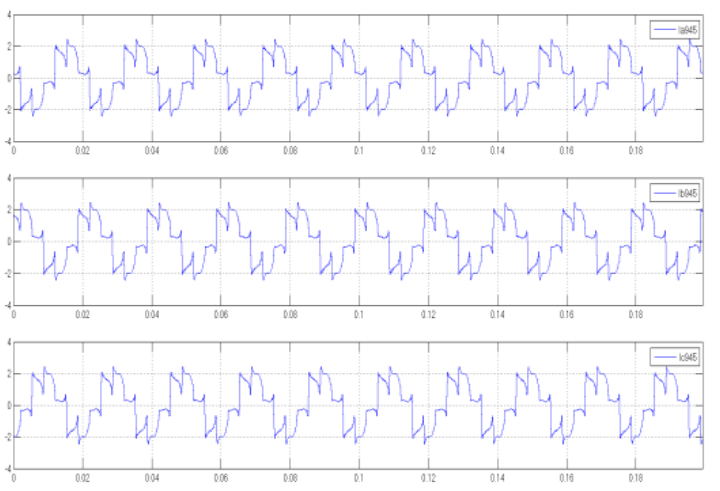

Gambar 8. Hasil simulasi pemodelan beban nonlinier untuk LHE 945 Watt

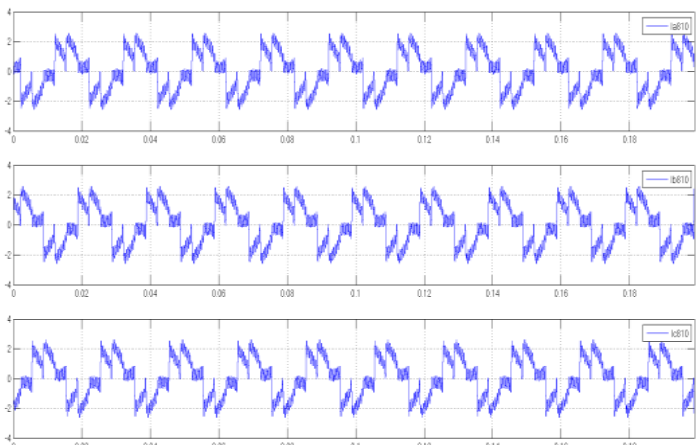

Gambar 9. Hasil simulasi pemodelan beban nonlinier untuk LHE 810 Watt
Gambar 9 memperlihatkan bentuk gelombang arus LHE 810 Watt yang terlihat sama namun bergeser $120^{\circ}$ antara fasa $a$, fasa $b$ dan fasa c.

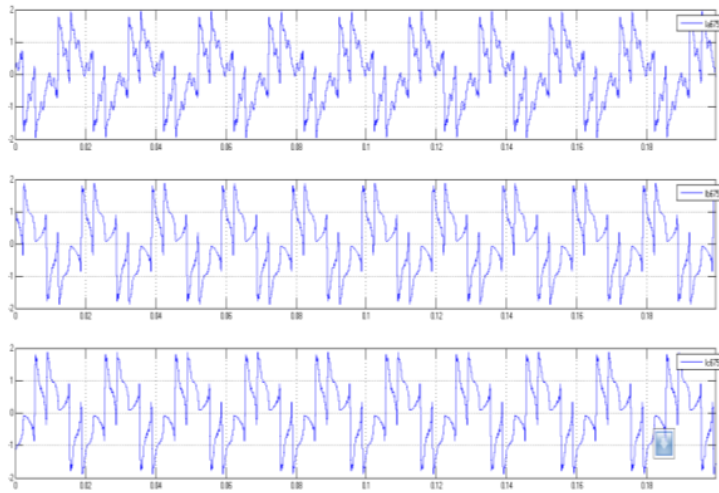

Gambar 10. Hasil simulasi pemodelan beban nonlinier untuk LHE 675 Watt

Gambar 10 memperlihatkan bentuk gelombang arus LHE 675 Watt yang terlihat sama namun bergeser $120^{\circ}$ antara fasa $a$, fasa $b$ dan fasa c.

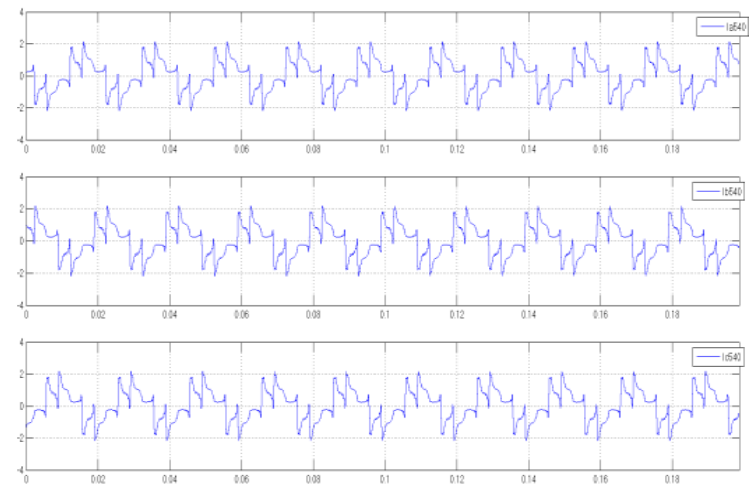

Gambar 11. Hasil simulasi pemodelan beban nonlinier untuk LHE 540 Watt

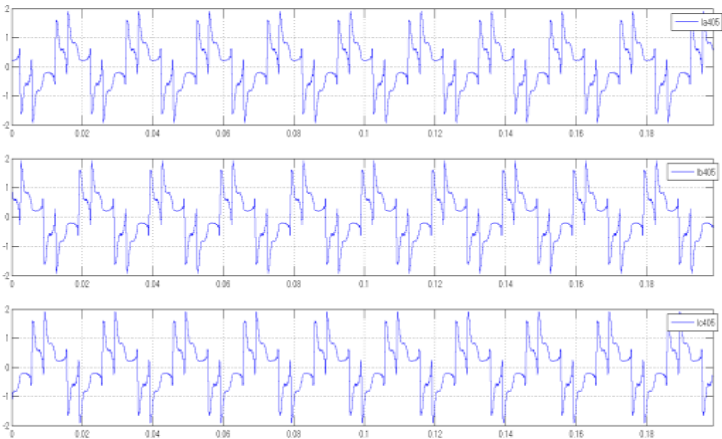

Gambar 12. Hasil simulasi pemodelan beban nonlinier untuk LHE 405 Watt 
Gambar 11 memperlihatkan bentuk gelombang arus LHE 540 Watt yang terlihat sama namun bergeser $120^{\circ}$ antara fasa $a$, fasa $b$ dan fasa c.

Gambar 12 memperlihatkan bentuk gelombang arus LHE 405 Watt yang terlihat sama namun bergeser $120^{\circ}$ antara fasa $a$, fasa $b$ dan fasa c.

Dari gambar 8 sampai 12 terlihat bahwa hasil simulasi memiliki pola arus yang sama dengan hasil pengukuran saat uji laboratorium menggunakan Power Analyzer seperti yang diperlihatkan gambar 13 sampai gambar 17.

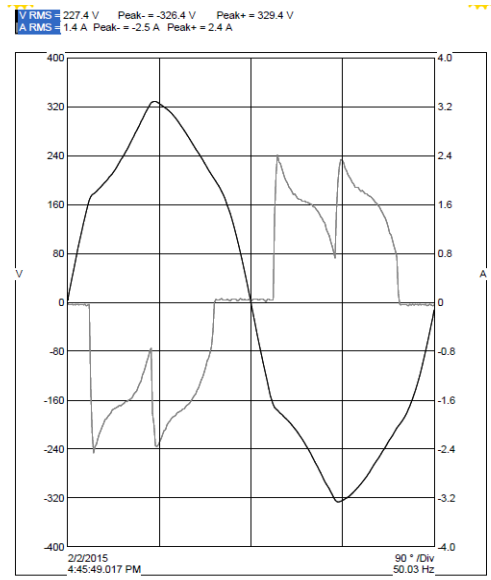

Gambar 13. Bentuk gelombang harmonisa arus dan tegangan pegukuran sisi LHE saat beban $945 \mathrm{~W}$

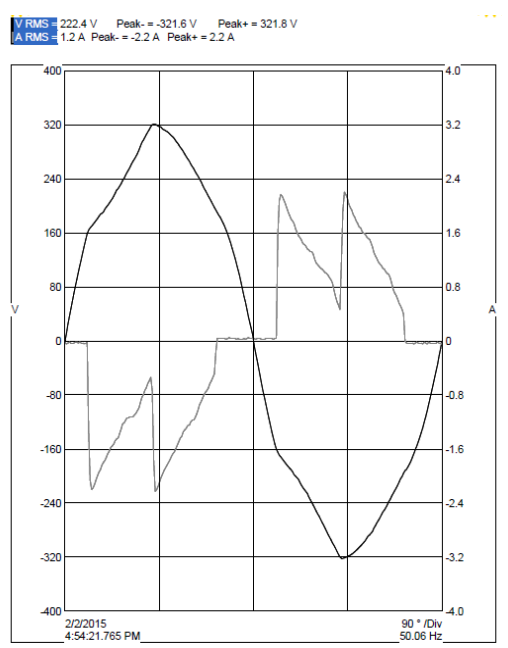

Gambar 14. Bentuk gelombang harmonisa arus dan tegangan pegukuran sisi LHE saat beban $810 \mathrm{~W}$

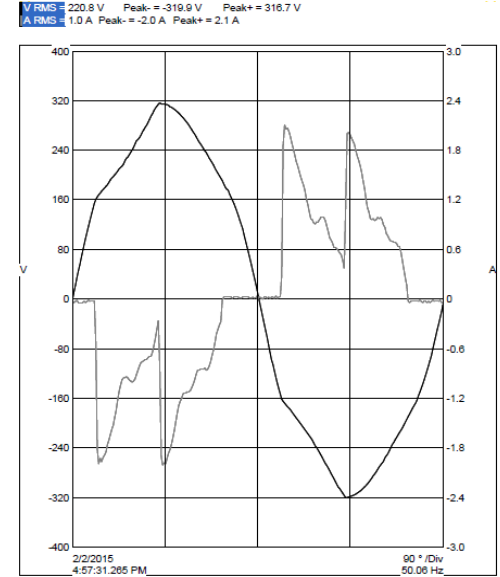

Gambar 15. Bentuk gelombang harmonisa arus dan tegangan pegukuran sisi LHE saat beban $675 \mathrm{~W}$

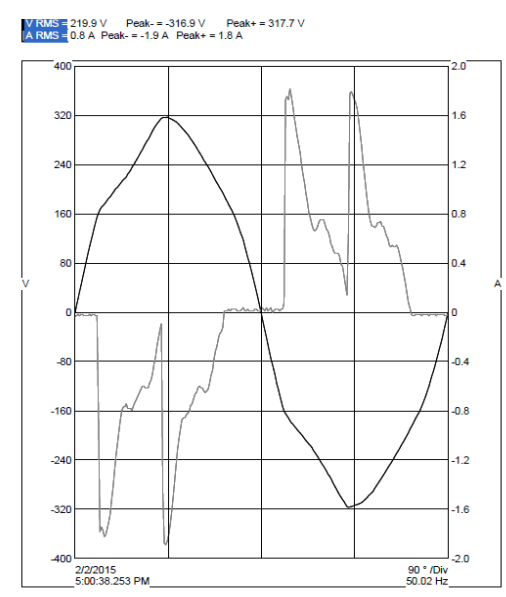

Gambar 16. Bentuk gelombang harmonisa arus dan tegangan pegukuran sisi LHE saat beban $540 \mathrm{~W}$

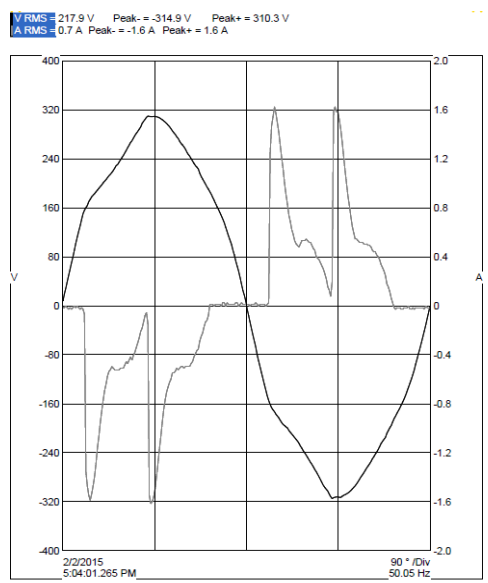

Gambar 17. Bentuk gelombang harmonisa arus dan tegangan pegukuran sisi LHE saat beban $405 \mathrm{~W}$ 
Bila kita bandingkan hasil simulasi dengan hasil pengujian laboratorium terlihat hasil sudah mirip dan saling mendukung. Dengan demikian dapat dinyatakan pemodelan ini sudah berhasil dan dapat diterapkan untuk memodelkan berbagai jenin beban non-linier lainnya tanpa menggunakan pendekatan matematis. Metode ini terasa sangat membantu untuk menganalisa pengaruh beban non-linier terhadap sumber maupun terhadap beban lain di sistem yang sama. Untuk sistem besar yang lebih komplek, metode ini juga sangat membantu dalam mendisain filter guna tujuan kompensasi nantinya.

\section{KESIMPULAN}

1. Pembuatan model beban non-linier 3-fasa menggunakan sumber arus pada simulink MATLAB berhasil dilakukan.

2. Pengujian laboratotium dan simulasi memberikan hasil yang saling mendukung menujukkan validitas yang baik dari model yang diusulkan

3. Pembuatan model beban nonlinier 3-fasa dengan menggunakan sumber arus ini dapat digunakan sebagai acuan pemodelan beban non-linier apa saja dengan menggunakan data komponen arus harmonik yang di serapnya, tanpa harus menurunkan persamaan dari rangkaian ekivalen beban nonlinier yang ingin dihitung

4. Dapat digunakan sebagai dasar pembuatan filter dan analisa sistem pada sistem besar.

\section{DAFTAR PUSTAKA}

[1] Nazir, Refdinal, " Analisys of Harmonic Current Propagation on the Self Excited Induction Generator with Nonlinear Loads", J Electr Eng Technol Vo. 9 No. 6, 2014

[2] AL-Kandari, A, EL-Naggar, K , "Time Domain Modeling and Identification of Nonlinear Loads Using Discrete TimeFiltering Estimator", 0-7803-8 1106/03/\$17.00 02003 IEEE.

[3] R.R.N, Souza, P.F. Ribeiro, "Non Linear Load Analysis : A discrete Modeling Based-Method", $\quad$ Conferencia International de Application Industry (Indusco), 2008
[4] Alexander Kusko and Marc T. Thompson, "Power Quality in Electrical Systems", Mc Graw Hill, 2007

[5] "IEEE Recommended Practices and Requirements for Harmonic Control in Electrical Power Systems", Revision of IEEE Std 519-1981 Second Printing 15 June 2004

[6] Masri, Syafrudin,"Pemodelan dan Prediksi Distorsi Harmonisa pada Utiliti Listrik Perumahan yang Disebabkan oleh Beban Nonlinier" , IES Politeknik Elektronika Negeri Surabaya - ITS, 2004

[7] Sankaran, C, " Power Quality", CRC Press LLC, New york,2002

\section{Biodata Penulis}

Rizka Amalia, Lahir di Bukittinggi pada tahun 1983. Menerima gelar sarjana dari Fakultas Teknik Universitas Andalas pada tahun 2006. Tahun 2003-2006 aktif sebagai asisten Laboratorium Konversi Energi Elektrik. Dan sekarang ini tengah menyelesaikan pendidikan jenjang Magister Teknik Elektro Universitas Andalas Padang. 